\title{
NOVÉ POZNATKY VE VÝPOČTU ODEZVY PODLOŽÍ VYSOKORYCHLOSTNIÍCH TRATÍ NA PRŮJEZD VLAKU
}

\author{
NEW FINDINGS IN CALCULATING OF THE SUBGRADE RESPONSE ON \\ HIGH-SPEED LINES TO TRAIN PASSAGE
}

\author{
Michal Petýrek ${ }^{*}, 1$ Leoš Horníček ${ }^{1}$
}

*michal.petyrek@fsv.cvut.cz

${ }^{1}$ ČVUT v Praze, Fakulta stavební, Katedra železničních staveb, Thákurova 7, 16629 Praha 6

\begin{abstract}
Abstrakt
Článek představuje možnosti př́stupů $\mathrm{k}$ výpočtu odezvy podloží železniční tratě na jízdu vlakových souprav vysokou rychlostí se zaměřením na projevy Rayleighova vlnění. Podrobněji je popsán přístup k výpočtu pomocí metody tenkých vrstev, který se jeví jako perspektivní pro výpočet odezvy tratě s konstrukcí koleje s príčnými pražci. Na tuto metodu je článek zaměřen $\mathrm{s}$ ohledem na předpokládané využití koleje $\mathrm{s}$ příčnými pražci na vysokorychlostních tratích v České republice. Dále je v článku zmíněna implementace nelineárního chování zeminy pod dynamickým zatížením při průjezdu vlaku a problematika výpočtu podloží tratě tvořeného více vrstvami zeminy s různými parametry.
\end{abstract}

\section{Klíčová slova}

Rayleighovo vlnění, vysokorychlostní trat', metoda tenkých vrstev, dynamické zatížení

\begin{abstract}
The article presents the possibilities of approaches to the calculation of the subsoil response of a railway line to high-speed train running with a focus on Rayleigh waves. The article describes in more detail the approach to the calculation using the method of thin layers, which seems promising for the calculation of the response of the track with the construction of the track with transverse sleepers. The article is focused on this method with regard to the expected use of the track with sleepers on high-speed lines in the Czech Republic. Furthermore, the article mentions the implementation of nonlinear behaviour of soil under dynamic load during the passage of the train and the issue of calculating the subsoil of the line formed by multiple layers of soil with different parameters.
\end{abstract}

\section{Key words}

Rayleigh waves, high speed track, method of thin layers, dynamic loading

\section{1 ÚVOD}

V souvislosti se zvyšující se rychlostí jízdy vlaků se začaly objevovat nové problémy, které se dosud při provozování železniční dopravy neobjevily, a bylo a je nutné je řešit. Mezi ně patří i dynamická odezva podloží železniční tratě na průjezd vlaku. Pokud se rychlost jízdy vlaku prribližíi nebo vyrovná rychlosti šíření Rayleighova vlnění zeminou, dochází k výrazné interferenci. Ta se projevuje významným nárưstem velikosti amplitud vibrací podloží železniční trati. Jejich zvětšení pak mají negativní dopad na konstrukce v okolí trati a teoreticky může vést až k vykolejení vlaku. U obce Ledsgard ve Švédsku, kde byly tyto projevy poprvé prakticky pozorovány při rychlosti vlaků cca $200 \mathrm{~km} / \mathrm{h}$, došlo $\mathrm{k}$ posunu a naklonění podpěr trakčního vedení. Tato problematika je v praktické rovině známa a řešena již déle než 20 let, předtím se jednalo o teoretický problém. [1], [2]

$\mathrm{V}$ současné době jsou $\mathrm{v}$ Evropě $\mathrm{v}$ provozu nebo $\mathrm{v}$ př́ípravě železniční tratě $\mathrm{s}$ rychlostí jízdy vlaků až $400 \mathrm{~km} / \mathrm{h}$ a i v České republice je prípravována výstavba tratí s maximální rychlostí $320 \mathrm{~km} / \mathrm{h}$. Dosavadní rychlostní rekord na trati klasické konstrukce $574,8 \mathrm{~km} / \mathrm{h}$ byl dosažen při zkušební jízdě speciálně upravené 
jednotky TGV ve Francii. Z toho lze predikovat, že časem dojde k dalšímu zvýšení rychlosti provozu vlaků a problematika Rayleighova vlnění nabyde ještě větší důležitosti [1].

\section{STRUČNÝ PŘEHLED PŘÍSTUPŮ K MODELOVÁNÍ PROBLEMATIKY RAYLEIGHOVA VLNĚNÍ}

K výpočtu chování podloží s ohledem na projevy Rayleighova vlnění železniční trati lze přistoupit z několika směrů.

Stávající předpisy pro vysokorychlostní tratě řeší chování konstrukce tratě pomocí základních funkcí odezvy konstrukce na statické zatížení a dynamické projevy zohledňují na základě rychlosti vlaků pomocí dynamického součinitele. Tento přístup je nedostačený, nebot' nezohledňuje specifické chování zeminy zmíněné v úvodu [3].

$\mathrm{Z}$ důvodu přesnějšího stanovení chování podloží bylo vyvinuto a v odborné literatuře prezentováno několik dalších př́istupů, z nichž každý má své výhody a nevýhody.

\section{Analytický př́stup}

Analytický přístup je založen na výpočtu působení pohyblivého zatížení na pružnoplastické podloží. Tento přístup umožňuje analýzu disperzních charakteristik koleje a jejího podloží. Kritická rychlost je pak stanovena z disperzních křivek. Z hlediska náročnosti prováděných výpočtů je tento přístup nejméně náročný, ale získané výsledky nejsou př́liš přesné [3], [4].

\section{Metoda konečných prvků}

Výpočet metodou konečných prvků ve 2D neposkytuje dostatečně přesné výsledky, nebot' je nelze snadno interpretovat ve 3D. Naopak výpočet založený na metodě konečných prvků ve 3D poskytuje velmi přesné výsledky. Nevýhodou toho prŕstupu je však náročná tvorba modelu. Všechny prvky konstrukce koleje musí být vymodelovány pomocí elementů. Další nevýhodou tohoto př́stupu je značná výpočetní náročnost [5], [6].

\section{Semi-analytický př́stup}

Semi-analytický přístup využívá pro výpočet chování kolejového roštu analytický přístup. Pro výpočet chování kolejového roštu a podloží pak využívá výpočet ve 3D pomocí Greenovy funkce pro zohlednění frekvenčních oblastí vlastních čísel. Výpočet odezvy kolejového roštu a podloží tratě probíhá odděleně. Tento př́stup umožňuje lepší popis vztahu mezi rychlostí pohybu zatížení (vlaku) a velikostí amplitud odezvy podloží při zachování relativně malé výpočetní náročnosti. Navzdory podrobnějšímu modelu podloží železniční trati tento př́istup neposkytuje příliš přesné výsledky [3], [4].

\section{2,5 D modelování}

Tzv. 2,5 D modelování zavádí zjednodušení oproti 3D modelování metodou konečných prvků (dále též "MKP"), ale míra zjednodušení vazeb $\mathrm{v}$ podloží není tak značná, jako $\mathrm{v}$ př́ípadě jiných analytických nebo semianalytických metod.

Metoda je založena na rozložení výpočtu do jednotlivých $2 \mathrm{D}$ př́íných řezů. Převod výsledku do $3 \mathrm{D}$ je zajištěn pomocí transformace. Výhodou tohoto kroku je výrazné omezení potřebné výpočetní kapacity. V př́ípadě výskytu problematických míst lze v modelu tato problematická místa řešit pomocí MKP ve 3D [3]. Nevýhodou tohoto př́istupu je jeho omezená použitelnost pouze pro konstrukci koleje s pevnou jízdní dráhou. V případě konstrukce koleje s pražci tento prrístup neumožňuje zohlednit mezeru mezi pražci [4].

\section{Metoda tenkých vrstev}

Pro výpočet odezvy podloží koleje s pražci bylo vyvinuto několik modelů vycházejících z výpočtu pomocí semianalytického přístupu. Složitost výpočtu zeminy a podloží pomocí MKP ve $3 \mathrm{D}$ zjednodušují výpočtem jejich chování na několika tenkých vrstvách a pružném poloprostoru. Tímto př́stupem je zajištěna přesnost získaných výsledků a nižší výpočetní náročnost [4], [6]. 


\section{METODA TENKÝCH VRSTEV}

Tento př́istup se $\mathrm{v}$ současné době jeví pro řešení odezvy podloží tratě s pražci jako nejperspektivnější, nebot' v České republice je jako základní konstrukce koleje na vysokorychlostních tratích navržena kolej s príńcnými pražci v kolejovém loži.

Podloží železniční trati je modelováno jako sestava n- tenkých vrstev uložených na poloprostoru. Toto uspořádání umožňuje stanovit šiření vln i do hloubky zeminy. Výhodou tohoto uspořádání je i možnost výpočtu odezvy pro podloží s vrstvami zemin o různých parametrech, zejména s rozdílnou tuhostí. Jednotlivé výpočtové vrstvy modelu musí být paralelní a jejich tloušt'ka musí respektovat uvažovanou vlnovou délku. Tloušt'ka jedné vrstvy pak odpovídá $1 / 8$ uvažované vlnové délky. Velikost výchylek ve svislém směru se stanovuje aproximací výsledků pro jednotlivé vrstvy pomocí kvadratické funkce s parabolickým průběhem [6].

Výpočet kolejového roštu a kolejového lože bývá řešen analyticky. Zahrnuje všechny hlavní prvky, a to kolejnice, upevnění, pražce a kolejové lože. Přenos spočtených deformací a zatižení na pláni tělesa železničního spodku pro výpočet odezvy zeminy je řešen pomocí Greenovy funkce [6].

\section{NELINEÁRNÍ CHOVÁNÍ ZEMIN V PODLOŽÍ}

Dynamické účinky jízdy vlaku vyšší rychlostí způsobují dočasnou změnu parametrů podložní zeminy, zejména dočasné snižení její tuhosti. Tyto projevy se označují jako nelineární chování zeminy. Většina výpočetních modelů však uvažuje s jejím lineárním chováním. Zavedení nelineárního chování zeminy do výpočtu je poměrně komplikovaným problémem [7].

Č́st modelů popisujících chování lokality Ledsgard ve Švédsku, kde byly negativní projevy Rayleighova vlnění poprvé pozorovány, zohledňuje nelineární chování zeminy uvažováním dodatečně stanovené tuhosti zeminy. Tuhost zeminy byla stanovena iterací na základě porovnání výsledků modelu a měření in-situ. Právě při ověřování výsledků z modelů výše popsané lokality ve Švédsku byl vliv nelineárního chování zemin odhalen a potvrzena nutnost jeho zohlednění při výpočtech [8].

Pokud je zemina vystavena malému tahu nebo tlaku, její odezvu lze považovat za pružnou a lineární. Př́i dalším růstu napětí se však zemina přestává chovat lineárně. Se vzrůstajícím napětím dochází ke snížení tuhosti a zvýšení útlumu. K popisu tohoto chování je možné použít lineární funkci, a to sečnu nebo tečnu napětového diagramu. Postup zavedení do výpočtu je pak následující:

- Stanovení vlastností všech výpočtových vrstev zeminy podloží při nízkém napětí.

- Výpočet totálního a efektivního smykového napětí s využitím všech elementů.

- Využití diagramu tuhost-napětí, což jsou funkce napětí a indexu plasticity, pro zpřesnění tuhosti každé vrstvy.

- Využití diagramu útlum-napětí, což jsou funkce napětí a indexu plasticity, pro zpřesnění útlumu každé vrstvy.

- Pokud je spodní vrstva tvořena pružným poloprostorem bez hranic, má stejné vlastnosti jako vrstva nad ní.

Postup výpočtu popsaný výše se opakuje, dokud se hodnota smykového modulu a útlumu prostřední vrstvy nerovná předchozímu kroku iterace, rozdíl může být maximálně $3 \%$ [8].

\section{PROBLEMATIKA VÝPOČTU VÍCEVRSTEVNATÉHO PODLOŽÍI}

V přirozených podmínkách v České republice je běžné stř́íání vrstev zemin s různými vlastnostmi. Dále je nutné počítat i s vlivem skalního nebo poloskalního podloží, pokud je mělce pod terénem. V̌etšina jednodušších výpočtů uvažuje s homogenním podložím. Metoda MKP nebo metody využívající ve výpočtu tenké vrstvy umožňují zohlednit vrstvy s různými vlastnostmi v podloží železniční trati.

$\mathrm{V}$ př́ípadě vrstvy s nižší tuhostí tvořící povrch terénu a pod ní se nacházejících vrstev s vyšší tuhostí jsou podle výsledků matematického modelu pro kritickou rychlost zeminy klíčové parametry horní vrstvy zeminy. Ale oproti výsledkům na homogenním podloží tvořeném zeminou s nízkou tuhostí jsou výsledky rozdílné. V případě inverzního uspořádání modelové situace, tj. vrstva $s$ vyšší tuhostí tvoří povrch terénu a pod ní se nachází vrstva s nižší tuhostí, vychází z matematického modelu dvě hodnoty kritické rychlosti, pro každou vrstvu jiná. Nižší kritická rychlost je pro spodní vrstvu s nižší tuhostí a vyšší kritická rychlost pro horní, tužší 
vrstvu. Čím větší je rozdíl v tuhosti mezi vrstvami v posledním popisovaném případě, tím větší je rozdíl mezi oběma kritickými rychlostmi [1], [2].

\section{ZÁVĚR}

Cílem článku bylo čtenáře seznámit s různými přístupy $\mathrm{k}$ teoretickému výpočtu dynamické odezvy podloží vysokorychlostní tratě na průjezd vlakové soupravy se zaměřením na projevy Rayleighova vlnění. V první části jsou pro přehlednost uvedeno pět běžně používaných přístupů. V přehledu jsou uvedeny i již překonané př́istupy, a to modelování ve 2D a analytický přístup, u nichž je známo, že neposkytují dostatečně přesné výsledky.

Mezi perspektivní metody řešení problematiky se řadí modelování problematiky pomocí MKP ve 3D. Velkou nevýhodou je však značná výpočetní náročnost. Pro konstrukci koleje s pevnou jízdní dráhou se jako vhodnější jeví metoda modelování ve 2,5D. Pro výpočet koleje s klasickou konstrukcí s př́íčnými pražci se jako nejvhodnější jeví metoda výpočtu pomocí tenkých vrstev. Obě metody využívají semi-analytický př́istup a mají nižší výpočetní náročnost než plné řešení problematiky MKP ve 3D, nebo i než semi-analytický př́stup, kdy pouze podloží železniční tratí je řešeno MKP.

V další kapitole je podrobněji popsána metoda s výpočtem pomocí tenkých vrstev. Článek je na tuto metodu zaměřen ze dvou důvodů. Jednak se v České republice předpokládá jako základní konstrukce koleje vysokorychlostních tratí kolej s př́ínými pražci. Druhým důvodem je využití konstrukce koleje s příčnými pražci v úseku, kde na standardní trati probíhá dlouhodobé sledování chování lokality s rizikovou geologií z hlediska Rayleighova vlnění. V rámci zde prováděného sledování se předpokládá vytvoření matematického modelu.

V článku jsou dále uvedeny aspekty, které se v rámci zdokonalování metody výpočtu v zahraničí aktuálně řeší, a to nelineární chování zemin a problematika modelování vícevrstevného podloží s vrstvami o různých parametrech. Obě problematiky jsou důležité, nebot' v př́ípadě nezohlednění nelineárního chování zeminy vychází výsledky z modelování odlišně od výsledků měření in situ. Problematika modelování vícevrstvého podloží je v České republice též nutná, nebot' podloží železniční tratě je ve většině př́ípadů vrstevnaté.

Získané poznatky budou využity pro další fázi výzkumu v rámci zpracovávání disertační práce.

\section{Poděkování}

Tato práce byla podpořena grantem Studentské grantové soutěže ČVUT č. SGS SGS21/103/OHK1/2T/11.

\section{Použité zdroje}

[1] COSTA, Pedro Alves, Aires COLAÇO, Rui CALÇADA a António Silva CARDOSO. Critical speed of railway tracks. Detailed and simplified approaches. Transportation Geotechnics [online]. 2015, (2), 30-46 [cit. 2021-11-01]. Dostupné z:

https://www.sciencedirect.com/science/article/pii/S2214391214000348

[2] COSTA, Pedro Alves, Paulo SOARES, Aires COLAÇO, Patrícia LOPES a David CONNOLLY. Railway critical speed assessment: A simple experimental-analytical approach. Soil Dynamics and Earthquake Engineering [online]. 2020, 2020, (134) [cit. 2021-11-01]. Dostupné z:

https://www.sciencedirect.com/science/article/pii/S0267726119312138?via\%3Dihub

[3] CHUMYEN, P., D.P. CONNOLLY, K. DONG, P.A. COSTA, P.J. SOARES a P.K. WOODWARD. The use of multiple models to analyse railway track ground dynamics. EURODYN 2020: XI International Conference on Structural Dynamics [online]. 2020, 2718 - 2728 [cit. 2021-11-01]. Dostupné z: https://www.easdprocedia.org/conferences/easd-conferences/eurodyn-2020/9223

[4] CHAROENWONG, C., CONNOLLYonnolly, D. P., DONGong, K., ALVESlves COSTAosta, P., SOARESoares, P. J., \& WOODWARDoodwar, P. K. (2022). A Multi-model Approach to Analyse Railway Track-Ground Dynamics and Soil Nonlinearity. In E. Tutumluer, S. Nazarian, I. Al-Qadi, \& I. I. A. Qamhia (Eds.), Advances in Transportation Geotechnics IV (pp. 37-48). (Lecture Notes in Civil Engineering; Vol. 165). Springer. https://doi.org/10.1007/978-3-030-77234-5_4

[5] HORTON, M., Z. YU a D. P. CONNOLLY. Settlement performance of geogrid-stabilised sub-ballast using simulated high-speed rail forces. In: IGSTI 2018. 2018, s. 424-429.

[6] CONNOLLY, D.P. a P. Alves COSTA. Geodynamics of very high speed transport systems. Soil Dynamics and Earthquake Engineering [online]. 2020, (130) [cit. 2021-11-01]. Dostupné z: https://www.sciencedirect.com/science/article/pii/S0267726119308322

[7] DONG, K., P. Alves COSTA, O. LAGHROUCHE, P.K. WOODWARD a D. P. CONNOLLY. Soil non-linearity on high speed railway lines. COMPDYN 2019: 7th ECCOMAS Thematic Conference 
on Computational Methods in Structural Dynamics and Earthquake Engineering [online]. 2019 [cit. 2021-11-01]. Dostupné z: https://files.eccomasproceedia.org/papers/compdyn2019/18466.pdf?mtime $=20191122131815$

[8] DONG, K., D.P. CONNOLLY, O. LAGHROUCHE, P.K. WOODWARD a P. ALVES COSTAC. Nonlinear soil behaviour on high speed rail lines. Computers and Geotechnics [online]. 2019, (112), 302318 [cit. 2021-11-01]. Dostupné z:

https://www.sciencedirect.com/science/article/pii/S0266352X1930103X?via\%3Dihub 